А.В. Писарєв ${ }^{1}$, І.О. Радченко ${ }^{1}$, А.Ф. Лазутський ${ }^{2}$, С.А. Тузіков ${ }^{3}$, С.А. Писарєв ${ }^{4}$, В.А. Молодцов ${ }^{1}$

${ }^{1}$ Національна академія Національної гвардї Украйни, Харків

${ }^{2}$ ДПТНЗ “Харківське вище професійне училище сфери послуг”, Харків

${ }^{3}$ Харківський національний університет Повітряних Сил ім. І. Кожедуба, Харків

${ }^{4}$ Інститут танкових військ НТУ “ХПI”, Харків

\title{
АНАЛІЗ СПОСОБІВ ДЕЗАКТИВАЦІЇ ЕЛЕМЕНТІВ ОЗБРОЄННЯ ОБМЕЖЕНОГО РОЗМІРУ 3 ВИКОРИСТАННЯМ ЕЛЕКТРИЧНОГО ПОЛЯ
}

В даній статті авторами розглянуто актуальне питання збільшення ефективності дезактивації зразків озброєння і військової техніки при використанні рідинних способів за умови застосування спільної дії електричного поля і хімічних реагентів, щุо утворюють дезактивуючий розчин. Проведений детальний аналіз та теоретичні розрахунки результатів занурення зразків озброєння в дезактивуючий розчин, щуо значно підвищує ефективність обробки у порівнянні з водним середовищем, електрохімічна дезактивація призводить до подальшого зростання ефективності обробки. Описаний зв'язок між витратами електроліту, напругою між електродами та питомою швидкістю розчинення верхнього забрудненого шару обладнання. Проведений порівняльний аналіз ефективної дезактивації в залежності від щільності струму та тривалості обробки, наведені переваги використання електрохімічної дезактивації. Зроблено висновки про можливе поєднання дії електричного поля і іонообмінної адсорбиї̈, електричного поля і механічних зусиль, використання імпульсного реверсного і особливо знакозмінного струму.

Ключові слова: електрохімічна дезактивація, хімічна дезактивачія, ефективність дезактивації, коефіцієнт дезактивації, повнота дезактивації, напівсухий спосіб електричної дезактивації.

\section{Вступ}

Постановка проблеми. Процес дезактивації, зворотній процесу радіоактивного забруднення (РА) забруднення, пов'язаний з видаленням РА забруднень з оброблюваних об'єктів. У разі випадку поверхневого забруднення дезактивація обмежується видаленням 3 поверхні об'єктів РА речовин, які закріплялися на ній в результаті адгезії і адсорбції молекул або іонів радіонуклідів (РН). Для дезактивації при глибинному забрудненні цього недостатньо - виникає необхідність вилучити РА забруднення, що проникли в глиб поверхні, і тільки після цього відбувається видалення РА забруднень, що перейшли з глибини на поверхню об'єкта. Можливе видалення РА забруднень, що перейшли з глибини на поверхню об’єкта. Можливе видалення РА забруднень, що знаходяться в глибині матеріалу, разом $з$ цим матеріалом.

Дезактивація здійснюється за допомогою різноманітних способів. Спосіб дезактивації - це сукупність операцій з використанням засобів дезактивації щодо видалення РА забруднень з об'єктів або 3 ізоляції поверхонь цих об'єктів. Способи дезактивації реалізуються в результаті впливу дезактивуючих розчинів (ДР) або середовищ на оброблювану поверхню з урахуванням особливостей об'єкта і використованих технічних засобів (Т3).

Способи дезактивації, що існують, можна кла- сифікувати за різноманітними ознаками. які, з одного боку, визначаються умовами РА забруднення, а 3 іншого - умовами проведення самої дезактивації. Вибір способу дезактивації диктується особливостями РА забруднень і самого об'єкта. В основу класифікації всіх способів дезактивації можуть бути покладені два основних принципи, що визначають агрегатний стан дезактивуючого середовища і особливості проведення власне дезактивації.

В залежності від агрегатного стану дезактивуючого середовища всі способи дезактивації можна поділити на рідинні і безрідинні, а також комбіновані.

Рідинні способи можуть бути засновані на використанні механічної дії (струмінь води, ультразвук, електричне поле, тощо) розчинів із застосуванням фізико-хімічних процесів адсорбційних, іоннообмінних, тощо), а також на поєднанні різноманітних видів дії. Дана проблема досліджувалась у низці теоретичних робіт [1-10].

Суттєвим недоліком цих досліджень є неможливість визначити ефективність і повноту дезактивації елементів озброєння обмеженого розміру.

Аналіз останніх досліджень і публікацій. Аналіз робіт [1-4; 7; 9-10; 13-14] показує, що з появою нових способів видалення радіоактивних речовин після ліквідації аварій на об'єктах атомної енергетики важливим $є$ підвищення ефективності дезак- 
тивації, особливо елементів озброєння обмеженого розміру. Відсутність теоретичних і експериментальних даних, необхідних для вирішення питань щодо підвищення ефективності дезактивації елементів озброєння і приладів обмеженого розміру і визначають актуальність цієї статті.

Мета статті - обгрунтування, удосконалення і доповнення шляхів видалення радіоактивних речовин 3 елементів озброєння обмежених розмірів, зокрема дезактивації з використанням електричного поля та поглиблення вже відомих підходів щодо підвищення ефективності дезактивації.

\section{Виклад основного матеріалу}

Електрохімічна дезактивація заснована на видаленні РА забруднень в результаті спільної дії електричного поля і хімічних реагентів, що утворюють ДР. При пропусканні електричного струму відбувається перехід поверхневого шару разом з РА забрудненнями в розчин (перша стадія процесу дезактиваціі). Потім (друга стадія процесу) РА забруднення видаляються разом з відпрацьованим розчином [3].

Роль ДР в цьому способі дезактивації виконує електроліт. Здійснення першої стадії процесу електрохімічної дезактивації схематично можна представити наступним шляхом: забруднена поверхня, щзо оброблясться, ДР + електроліт $\rightarrow$ оброблена ДР поверхня, ДР+РА забруднення.

Подібний процес може статися при зануренні забруднених виробів в електроліт (хімічна дезактивація), але під дією електричного поля (електрохімічна дезактивація) обробка відбувається інтенсивніше - за більш короткий час і з більшою ефективністю. Підтвердимо це прикладом [1, С. 161]. При дезактивації методом занурення пластини з нержавіючої сталі в ДР, що містить $41 \% \mathrm{H}_{3} \mathrm{PO}_{4}, 11 \% \mathrm{H}_{2} \mathrm{SO}_{4}$, $6 \% \mathrm{H}_{2} \mathrm{O}$ і 42\% гліцерину, а потім пропущені через пластину струму щільністю $880 \mathrm{MA} / \mathrm{M}^{2}$ отримані були наступні результати (для порівняння також приведені дані після обробки зануренням у воду), які наведені у табл. 1.

Коефіцієнт дезактивації (КД)

Таблиця 1

при забрудненні радіонуклідами (РН)

\begin{tabular}{|c|c|c|c|}
\hline \multirow{2}{*}{$\begin{array}{c}\text { Радіонуклідні } \\
\text { забруднювачі }\end{array}$} & \multicolumn{3}{|c|}{ Умови обробки } \\
\cline { 2 - 3 } & \multicolumn{2}{|c|}{ Занурення } & \multirow{2}{*}{ Електрохімічна } \\
\cline { 2 - 3 } & у воду & у ДР & \\
\hline${ }^{32} \mathrm{P}$ & 1,6 & 100 & 1000 \\
${ }^{59} \mathrm{Fe}$ & 1,1 & 250 & 1000 \\
${ }^{90} \mathrm{Sr}$ & 2,2 & 77 & 200 \\
${ }^{141} \mathrm{Ce}$ & 2,4 & 167 & $\rightarrow \infty$ \\
${ }^{124} \mathrm{Sb}$ & 1,3 & 2,8 & 21 \\
\hline
\end{tabular}

Джерело: розроблено авторами за даними: [1, с. 161].

3 табл. 1 випливає, що занурення зразків в ДР значно підвищує ефективність дезактивації, а електрохімічна дезактивація призводить до подальшого зростання ефективності обробки.

При дезактивації обладнання, а не пластин обмеженого розміру, ефективність обробки ще більш значна. Так, КД при зануренні деякого обладнання в ДР становить лише 2, а після електрохімічної обробки він збільшується до 180, при значному скороченні, на порядок і більше часу дезактивації. Крім того скорочується витрата електроліту.

Схематично процес електрохімічної дезактивації показаний на рис. 1 [1]. Оброблювані вироби 1, які в даному випадку служать анодом, занурені в ємність 3 ДР 3. Дезактивуючий розчин циркулює між оброблюваним виробом і катодом 2. Ця циркуляція, яка здійснюється довільно або за допомогою насоса 4, на рис. 1 показана стрілкою 5.

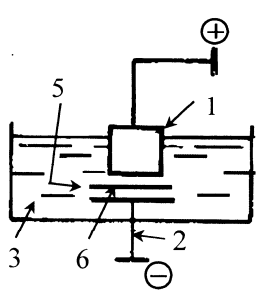

a

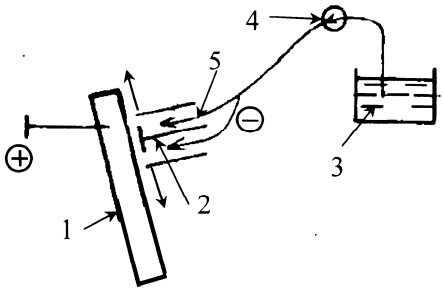

o
Рис. 1. Дезактивація в електричному полі за допомогою нерухомого (а) й рухомого (б) катоду:

1 - оброблювані вироби (анод); 2 - катод;

3 - дезактивуючий розчин; 4 - насос; 5 - напрям циркуляції розчину; 6 - діелектрична прокладка Джерело: розроблено авторами за даними [1, с. 161].

Ефективність електрохімічної дезактивації в загальному вигляді можна виразити таким чином:

$$
\mathrm{K}_{\text {д }}=(J, \Pi, \mathrm{E}, 3),
$$

де $J$ - щільність струму, А/ ${ }^{2}$;

П - основні параметри способу;

Е - склад електроліту (ДР);

3 - умови РА забруднення і властивості оброблюваних поверхонь.

До основних параметрів відносять витрату електроліту, напругу між електродами, питому швидкість розчинення верхнього забрудненого шару.

Залежно від механізму впливу електричного поля на оброблювану поверхню розмежовують значення щільності струму: при малій щільності струму 1-2 A/м² на оброблюваній поверхні утворюються сліди травлення, а при високій щільності (понад 10 $\mathrm{A} / \mathrm{M}^{2}$ ) - має місце електрополірування.

Щільності струму в межах $2-10 \mathrm{~A} / \mathrm{m}^{2}$ можна вважати середніми. Ефективність електрохімічної дезактивації, що проводили поступово протягом чотирьох циклів по 30 с кожний, сталевих поверхонь, забруднених $\mathrm{PH}^{204} \mathrm{Tl}$, в залежності від щільності струму наведено в табл. 2. 
Таблиця 2

Коефіцієнт дезактивації

\begin{tabular}{|c|c|c|c|c|}
\hline \multirow{2}{*}{ Дегазуючий розчин } & \multicolumn{4}{|c|}{ Щільність струму } \\
\cline { 2 - 5 } & 0 & 500 & 1000 & 2000 \\
\hline кислий $\left(0,2 \mathrm{H.} \mathrm{HNO}_{3}\right)$ & 9 & 112 & 278 & 330 \\
\hline лужний $\left(0,1 \mathrm{H.} \mathrm{KOH}^{2}\right)$ & 9 & 1,4 & 1,7 & 3,0 \\
\hline окислювач $\left(37,2 \% \mathrm{HClO}_{4}\right)$ & 11 & 165 & 200 & 350 \\
\hline
\end{tabular}

Джерело: розроблено авторами за даними [1, с. 162].

Наведені відомості демонструють переваги електрохімічної дезактивації, особливо в ДР на основі окислювачів. Електрохімічна дезактивація в лужному середовищі не ефективна. За іншими даними [4, С. 15], при щільності струму $2000 \mathrm{~A} / \mathrm{M}^{2}$ час дезактивації скорочується до 45 с, а КД коливається від 37 до 46 для різних сполучень електролітів, що містять кислоти. Зі збільшенням щільності струму зростає ефективність дезактивації. Так, при обробці протягом 12 с в 10\%-ому розчині $\mathrm{H}_{2} \mathrm{SO}_{4}$ зі збільшенням щільності струму від 1000 до $6000 \mathrm{~A} / \mathrm{M}^{2}$ КД (щодо нержавіючої сталі, початковий рівень забруд-

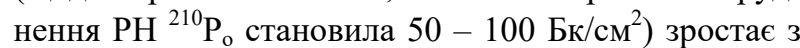
158 до 2000, а в $10 \%$-ому розчині $\mathrm{H}_{3} \mathrm{PO}_{4} 325$ до 500 [5, С. 27]. Щільність струму пов'язана з часом обробки, коли електрохімічна дезактивація проводилася по відношенню до сталевих поверхонь, забрудненим ${ }^{204} \mathrm{~T} 1$, в ДР $з$ 0,2 н, $\mathrm{HNO}_{3}$; спостерігається симбатне збільшення дезактивації в міру зростання щільності струму і часу обробки від 0,5 до 2 хвилин. Максимальний КД, рівний 700, досягається при двостадійній обробці при щільності струму, яку можна охарактеризувати як понад 1000 A/m². Дезактивація свинцевих поверхонь проводилась у кілька стадій. Перша, електрохімічна дезактивація, здійснювалася в розчині натрієвої солі щавлевої кислоти. На другій стадії поверхні промивалися розчином поверхнево активної речовини (ПАР). В подальшому ці дві стадії ще раз повторювалися. В іншому варіанті свинцеві поверхні оброблялися в розчині азотної кислоти 3 щільністю струму $500 \mathrm{~A} / \mathrm{M}^{2}$. Ефективність і швидкість електрохімічної дезактивації хромонікелевої сталі при щільності струму $20-40 \mathrm{\kappa A} / \mathrm{M}^{2}$ в двох різних розчинах (ФС - $10 \% \mathrm{H}_{3} \mathrm{PO}_{4}+2,5 \% \mathrm{H}_{2} \mathrm{SO}_{4}$ i $\Phi$ від 10 до $15 \% \mathrm{H}_{3} \mathrm{PO}_{4}$ ) наведено в табл. 3 .

Таблиця 3

Ефективність і швидкість електрохімічної дезактивації хромонікелевої сталі

\begin{tabular}{|c|c|c|}
\hline Електроліт ДР & ФС & $\Phi$ \\
\hline КД & $3-4 / 10^{-3}$ & $4-5 / 10^{4}$ \\
\hline $\begin{array}{c}\text { Продуктивність, } \\
10^{-3} \mathrm{~m}^{2} \text { (А/год) }\end{array}$ & $0,1-0,5$ & $5-7$ \\
\hline
\end{tabular}

Джерело: розроблено авторами за даними [1, с. 163].

В переважних випадках ефективність електро- хімічної дезактивації дуже добра [2, С. 172].

В якості електроліту Е застосовуються реагенти, що надають ДР кисле середовище, зокрема, такі кислоти як фосфорна, сірчана тощо, а також низка органічних кислот, в більшій частині - щавлева. Можливе використання і лужних електролітів, але ефективність їх нижче в порівнянні з кислотними, зате полегшується наступне очищення електролітичної ванни від РА забруднень [табл. 2].

Режими електрохімічної дезактивації визначаються складом електроліту. Так, у разі застосування фосфорної кислоти 3 концентрацією 40-80\% ефективна дезактивація досягається при електродному потенціалі 8-12 В і щільності струму 500-5000 A/ ${ }^{2}$, коли температура ДР знаходиться в межах $48-80{ }^{\circ} \mathrm{C}$ [7, C. $10 ; 8$, C. 53].

Крім того застосовують окислювачі та розчини ПАР, які так само впливають на режим дезактивації. При обробці сталевих поверхонь в $1 \%$-ому розчині сульфату натрію і щільності струму $200 \mathrm{~A} / \mathrm{M}^{2}$ КД досягає 500, що значно більше в порівнянні з дезактивацією без впливу електричного поля.

Електрохімічний спосіб застосовують для дезактивації сталевих і інших металевих поверхонь, забруднення яких здійснювалося окремими РН або їх сумішшю. Повнота дезактивації в значній мірі залежить від властивостей $\mathrm{PH}$, що забруднюють поверхню. КД в 0,1 н, розчині азотної кислоти при щільності струму $500 \mathrm{~A} / \mathrm{M}^{2}$, а для деяких РН-1000 $\mathrm{A} / \mathrm{M}^{2}$ (знаменник) 3 плином часу впливу і $\mathrm{PH}$ змінюється як показано в табл. 4.

Таблиця 4

Залежність КД від властивостей РН та часу впливу електричного поля

\begin{tabular}{|c|c|c|c|c|c|c|}
\hline \multirow{2}{*}{\begin{tabular}{c} 
КД при часі $\begin{array}{c}\text { дії } \\
\text { електрич- } \\
\text { ного поля }\end{array}$ \\
\cline { 2 - 7 }
\end{tabular}} & ${ }^{60} \mathrm{Co}$ & ${ }^{106} \mathrm{Rb}$ & ${ }^{124} \mathrm{Sb}$ & ${ }^{131} \mathrm{I}$ & ${ }^{137} \mathrm{Cs}$ & ${ }^{204} \mathrm{Tl}$ \\
\hline 1 хв. & 0 & $1,0 / 2,0$ & $2,0 / 60$ & $-/ 35$ & 220 & 50 \\
\hline 2 хв. & 50 & $2,5 / 8,1$ & $3,5 / 62$ & $-/ 36$ & 415 & 103 \\
\hline 3 хв. & 77 & $3,8 / 11,8$ & $3,8 / 69$ & $2,5 / 40$ & 580 & 107 \\
\hline 4 хв. & 98 & $4,3 / 12,3$ & $4,0 / 73$ & $4,0 / 42$ & 710 & 110 \\
\hline
\end{tabular}

Джерело: [1, с. 163].

Як видно з таблиці наведені дані свідчать про значний розкид значень КД від 1 до 710 і про вибіркову ефективність електрохімічної дезактивації.

При радіоактивному забрудненні різними $\mathrm{PH}$ відсутній єдиний режим, що зв'язує параметри обробки, щільність струму та склад ДР, тобто все те, що входить до умови 1.

Подібна ситуація має місце при електрохімічній дезактивації алюмінієвих поверхонь. КД при забрудненні сталевих поверхонь тими ж РН, що наведені в табл. 3 (за виключенням ${ }^{131} \mathrm{I}$ ) в кислому середовищі у залежності від щільності струму змі- 
нюється наступним чином (час впливу струму 1 хв) та наведені в табл. 5 [3].

Залежність КД

від властивостей РН та щільності струму

\begin{tabular}{|c|c|c|c|c|c|}
\hline \multirow{2}{*}{$\begin{array}{c}\text { КД при щільності } \\
\text { струму, А/м² }\end{array}$} & \multicolumn{5}{|c|}{ Радіонукліди } \\
\hline & ${ }^{60} \mathrm{Co}$ & ${ }^{106} \mathrm{Rb}$ & ${ }^{124} \mathrm{Sb}$ & ${ }^{137} \mathrm{Cs}$ & ${ }^{204} \mathrm{Tl}$ \\
\hline 0 & 250 & 2,6 & 1,8 & 123 & 51 \\
\hline 44 & 1000 & 11,5 & 3,4 & 330 & 500 \\
\hline 444 & $\rightarrow \infty$ & 3,8 & 4,0 & 200 & 500 \\
\hline
\end{tabular}

Джерело: [1, с. 164].

Наведені відомості при дезактивації сталевих і алюмінієвих поверхонь показують, що режими електрохімічної дезактивації повинні розроблятися 3 урахуванням забруднення РА і особливостей оброблюваних поверхонь. Залежність КД кислото-упорної сталі (у чисельнику - для води, у знаменнику - в 0,2 розчині сірчаної кислоти при щільності струму 28 $\mathrm{A} / \mathrm{M}^{2}$ ) від часу дезактивації і виду механічної обробки сталі змінюється наступним чином, табл. 6.

Як бачимо з табл. 6 досить 1 хв. дії електричного поля, щоб забезпечити надійну дезактивацію шліфованих і полірованих поверхонь. Необроблені поверхні, що мають значну шорсткість, у виїмку яких проникають РН, дезактивуються слабко.

Таблиця 6

Залежність КД кислото-упорної сталі від часу дезактивації і виду механічної обробки

\begin{tabular}{|c|c|c|c|}
\hline Час дезактивації, хв. & 1 & 2 & 10 \\
\hline КД поверхонь: & \multicolumn{3}{|l|}{} \\
\hline необроблених & $6 / 11$ & $8 / 33$ & $14 / 6$ \\
\hline шліфованих & $50 / 67$ & $67 / 83$ & $77 / 100$ \\
\hline полірованих & $67 / 500$ & $100 / 500$ & $\infty / \infty$ \\
\hline
\end{tabular}

Джерело: розроблено авторами за даними [1, с. 164].

У міру збільшення числа циклів забруднення дезактивація спостерігається різке зниження ефективності дезактивації (КД дорівнює 3 - 15) для всіх сталевих поверхонь, незалежно від ступеня обробки поверхні.

Дезактивація здійснюється в двох різних варіантах за допомогою стаціонарних установок, що мають електролітичну ванну для занурення оброблюваних виробів, і безпосередньо на місці при дезактивації великогабаритних об’єктів або агрегатів цих об'єктів. У зв'язку з цим розроблено два варіанти електрохімічного способу дезактивації з використанням нерухомого та рухомого катода 2 (рис. 1). При використанні рухомого катода ДР подається насосом 4 в простір між катодом і оброблюваним виробом. Катод в нерухомому варіанті виконується зі свинцю [9, С. 228] для кращого копіювання форми оброблюваної поверхні. Можлива заливка електро- літу в оброблюваний виріб, коли необхідно провести дезактивацію внутрішніх поверхонь різних ємностей.

Розміри оброблюваного об'єкта в варіанті нерухомого катода і в процесі занурення, вироби обмежені обсягом ванни для ДР. Крім того необхідно враховувати відстань між катодом і оброблюваним виробом, яке при щільності струму 10-20 А/ $\mathrm{M}^{2}$ досягає 1-5 мм.

Застосовується так званий напівсухий спосіб електрохімічної дезактивації [7, С. 12; 8 С. 25], коли між оброблюваним виробом (анодом) і свинцевим катодом застосовують прокладку 6 (рис. 1) 3 діелектрика (повсть, бавовняні і вовняні тканини), яку змочують електролітом. В одному з варіантів напівсухого методу [4, С. 12] в між електродному просторі містився пористий фетровий тампон, просочений електролітом. При щільності струму 1000 А/м² в 10 - 30\%-ному розчині $\mathrm{H}_{3} \mathrm{PO}_{3}$ КД досягає $700-1000$.

У деяких випадках для видалення надлишку електроліту, який дезактивує виріб, піддається промиванню, що передбачає наявність двох ванн; одну - електролітичну, іншу - промивальну.

В одному з варіантів дезактивації за допомогою рухомого катода (рис. 1) сила притиску катода до оброблюваної поверхні становила 40 - 400 Н. Під дією постійного струму (потенціал на електроді 6-30 В, щільність струму 2,5 кА/ ${ }^{2}$ ), коли швидкість подачі електроліту (суміш лимонної і сірчаної кислот) становила $2000-4000$ л/ч·м², КД коливався від 27 до 1800 в залежності від конфігурації оброблюваної поверхні. При обробці виробів складної конфігурації КД був мінімальним, що свідчить про недостатню ефективність дезактивації подібних поверхонь рухомим катодом.

В іншому варіанті електрохімічної дезактивації, коли щільність струму досягала великих значень (5-7·104 A/м² [5, С. 31], низькоомний електрод виконувався у вигляді щітки 3 вуглецевою тасьмою, яка має питомий опір $10^{-2}-10^{-3}$ Ом·см; для металів воно дорівнює $10^{-6}-10^{-4}$, а для діелектриків $1-20$ Ом·см. Вуглецева тасьма перешкоджає короткому замиканню і збільшує швидкість обробки до $6 \mathrm{~m}^{2}$ за 1 год. Дезактивації піддавалися поверхні складної конфігурації, забруднені $\mathrm{PH}{ }^{165} \mathrm{Ru},{ }^{240} \mathrm{Po}$, а також їх оксидами; повнота дезактивації була досягнута.

Можливо поєднання дії електролітичної дезактивації і водяної пари. Для цієї мети в щітці, що є катодом, змонтовані форсунки, через які водяна пара подає електроліт в розпиленому вигляді. Потенціал на електроді становив $10 \mathrm{~B}$, а сила струму 0,15 А. КД при використанні $10 \%$-ного розчину азотної кислоти склав близько 1000.

Ефективність електрохімічної дезактивації визначається особливостями оброблюваного об'єкта. 
При дезактивації за допомогою рухомого катода [5, С. 29] різних агрегатів демонтованого обладнання площею від 0,15 до 3,5 м² КД коливався від 30 до 200, а швидкість обробки від 0,6 до 6 м²/год. Ефективність дезактивації різних частин одного і того ж виробу неоднакова. При обробці циліндрів (щільність струму $233 \mathrm{~A} / \mathrm{m}^{2}$ ) в залежності від місця дезактивації отримані наступні значення КД, які наведені в табл. 7.

Таблиця 7

Ефективність дезактивації циліндричної поверхні

\begin{tabular}{|l|c|c|c|}
\hline $\begin{array}{l}\text { Місця дезактивації } \\
\text { циліндричної } \\
\text { поверхні }\end{array}$ & Верх & Середина & Дно \\
\hline $\begin{array}{l}\text { КД за час обробки, } \\
\text { хв. }\end{array}$ & \multicolumn{3}{|l|}{} \\
\hline \multicolumn{1}{|c|}{50} & 10 & 50 & 100 \\
65 & 34 & 140 & 170 \\
\hline
\end{tabular}

Джерело: розроблено авторами за даними [1, с. 166].

Електрохімічний спосіб дезактивації, незважаючи на деякі переваги (можливість видалення глибинних РА забруднень, значна ефективність, тощо) має ряд істотних недоліків.

Основними 3 них $є$ необхідність розробки і застосування дорогого устаткування, дотримання техніки безпеки при роботі під напругою і з агресивними середовищами.

У розробленому методі електрохімічної дезактивації [10] використовуються неагресивне середовище ( $\mathrm{pH}=6)$ і невеликі щільності струму. Метод заснований на застосуванні електрода 3 вуглецевої сталі, що витрачається, яка відновлює оксиди тривалентного заліза на поверхні обладнання і переводить їх у водорозчинний двовалентний стан.

За своєю ефективністю цей метод не поступається обробці в кислих агресивних розчинах.

На практиці апробовані різні варіанти впливу електричного поля на забруднену поверхню. Розглянемо деякі з них.

Електрохімічна дезактивація може бути реалізована в тому випадку, коли оброблювана поверхня $\epsilon$ не анодом (див. рис.1), а катодом. При нанесенні електроліту, наприклад, сірчаної кислоти, атомний водень, що виділяється при електролізі в результаті іонного обміну здатний витягувати РН із забрудненої поверхні, зокрема РН тритію [10].

Можливе поєднання дії електричного поля і iонообмінної адсорбції. Розроблено апарат для очищення води, названий авторами електродіалізатор [11-12].

Він заповнений сумішшю різних смол, здатних в результаті іонного обміну витягувати 3 водного середовища РН. Коефіцієнт очищення, який визначається відповідно до рівняння:

$$
\mathrm{K}_{\mathrm{O \Psi}}=v_{\mathrm{A}}^{\mathrm{H}} / v_{\mathrm{A}}^{\mathrm{K}},
$$

де $v_{\mathrm{A}}^{\mathrm{H}}, v_{\mathrm{A}}^{\mathrm{K}}-$ концентрація радіоактивних речовин (об'ємна активність) до і після дезактивації, дорівнює 100 - 3000. Причому зниження концентрації РН в очищуваному середовищі йде за механізмом кінетики першого порядку згідно рівняння

$$
\mathrm{A}_{\mathrm{K}}=\mathrm{A}_{\mathrm{H}} \cdot e^{-k t}
$$

де $\mathrm{A}_{\mathrm{K}}, \mathrm{A}_{\mathrm{H}}$ - активність радіоактивних речовин до $\mathrm{i}$ після дезактивації;

$k$ - константа швидкості дезактивації;

$t$ - час дезактивації.

Замість активності А в ці рівняння необхідно підставити початкове і кінцеве значення концентрації $\mathrm{PH} C_{\mathrm{H}}$ і $C_{\mathrm{K}}$. Визначено числові значення константи швидкості очищення, які дорівнюють 0,021 $0,124 \mathrm{xв}^{-1}$ в залежності від напруги на електродах i завантажуваної шихти.

Можливо поєднання дії електричного поля i механічних зусиль. Подібне поєднання було використано для руйнування бетонних структур [7-8] шляхом нагрівання залізної арматури бетону низьковольтним (менше 50 В) електричним струмом великої потужності, що призводить до ослаблення структури бетону і його розтріскування. Утворені тріщини дають можливість за допомогою невеликих механічних зусиль відокремити забруднені блоки бетону від основної маси. У порівнянні зі звичайними механічними методами (відбійним молотком, киркою, тощо) при видаленні бетону в 500 разів менше утворюється РА пил, збільшується продуктивність і виникає можливість застосування дистанційно-керованих систем.

Інтенсифікація процесу електрохімічної дезактивації досягається шляхом використання імпульсного, реверсивного і особливо знакозмінного струму. Проведені дослідження дозволили визначити оптимальні умови дезактивації змінним струмом поверхонь $з$ нержавіючої сталі: частота 50 Гц, щільність струму $20-30$ кА/м², електроліт складається 3 5 - 10\%-го розчину азотної кислоти, питома швидкість розчинення верхнього забрудненого шару, яка визначає ефективність дезактивації, дорівнює 180 200 мг/(А·год). Середня швидкість розчинення вуглецевої сталі збільшується і становить 200 - 400 мг/(А·год) [12, С. 215]; середня швидкість дезактивації коливається від 0,06 до $18 \mathrm{~m}^{2} /$ год.

За лабораторних умов проводилася дезактивація зразків розміром 40×40 мм 3 нержавіючої сталі, бронзи і цирконієвого сплаву, забруднених сумішшю $\mathrm{PH}{ }^{144} \mathrm{Ce} \mathrm{i}{ }^{137} \mathrm{Cs}$ в співвідношенні $1: 5$, після забруднення зразки прожарювались при $500{ }^{\circ} \mathrm{C}$ протягом 20 - 30 хв для фіксації глибинного забруднення. При обробці в полі змінного струму частотою 50 Гц нержавіючої сталі в 5\%-ому розчині азотної 
кислоти (щільність струму $500 \mathrm{~A} / \mathrm{M}^{2}$, час обробки 10 - 15 хв, швидкість дезактивації $100-200 \mathrm{~m}^{2} /$ (А·год.) товщина шару, що видаляється становила 1,6 - 4,0 мкм, що забезпечувало дезактивацію після глибинного РА забруднення. КД цирконієвого сплаву за цих же умов досягав $170-220$. Таким чином, розроблені та апробовані способи дезактивації під дією постійного і змінного струму.

\section{Висновки}

Результати, напрацьовані в ході дослідження за анонсованим у назві статті напрямом, у сукупності забезпечують можливість проведення електрохімічної дезактивації елементів озброєння обмеженого розміру в ДР на основі кислого середовища та особливо на основі окислювачів. Інтенсифікація процесу електрохімічної дезактивації досягається шляхом використання імпульсного, реверсивного і особливо знакозмінного струму. Ефективність електрохімічної дезактивації залежить від щільності струму та часу обробки - 3 їх збільшенням зростає і коефіцієнт дезактивації.

Проведений детальний аналіз та теоретичні ро- зрахунки результатів занурення зразків озброєння у дезактивуючий розчин, що значно підвищує ефективність обробки у порівнянні з водним середовищем, електрохімічна дезактивація призводить до подальшого зростання ефективності обробки. Описаний зв'язок між витратами електроліту, напругою між електродами та питомою швидкістю розчинення верхнього забрудненого шару обладнання. Проведений порівняльний аналіз ефективної дезактивації в залежності від щільності струму та тривалості обробки, наведені переваги використання електрохімічної дезактивації.

Проведено обгрунтування, удосконалення і доповнення шляхів видалення радіоактивних речовин 3 елементів озброєння обмежених розмірів, зокрема дезактивації з використанням електричного поля та поглиблення вже відомих підходів щодо підвищення ефективності дезактивації.

Зроблено висновки про можливе поєднання дії електричного поля і іонообмінної адсорбції, електричного поля і механічних зусиль, використання імпульсного реверсного і особливо знакозмінного струму.

\section{Список літератури}

1. Зимон А. Д. Дезактивация. Москва : Изд. АТ, 1994. 336 с.

2. Писарєв А. В., Радченко І. О., Тузіков С. А., Писарєв С. А., Лазутський А. Ф. Методика оцінки ступеня і повноти дезактивації об'єктів, забруднених радіоактивними речовинами. Збірник наукових праць Харківського національного університету Повітряних Сил. 2017. № 2(51). С. 170-174. https://doi.org/10.30748/zhups.2017.51.03.

3. Писарєв А. В., Радченко І. О., Тузіков С. А., Лазутський А. Ф., Писарєв С. А. Аналіз безрідинних способів дезактивації зразків озброєння, військової техніки та військових об'єктів. Збірник наукових праць Харківського національного університету Повітряних Сил. 2018.№ 2(56). С. 199-206. https://doi.org/10.30748/zhups.2018.56.03.

4. Blazek J., Przeczen B., Prazsku M., Zneskodnovanie Z. Jadrouyeh elektrarni. Nizke Tatry. 1988. No. 2. P. 11-29.

5. Захарчук Г. А., Балуков Р. В., Васильев Л. И. Химические технологии и вопросы надежной эксплуатации. Требования Всесоюзного проекта и НИИ комплексной энергетической техники. Ленинград : Наука, 1988. С. 27-33.

6. Зимон А. Д. Мир частиц - коллоидная химия для всех. Москва : Наука, 1988. 138 с.

7. Полуэктова Г. Б., Ковальчук О. В. Атомная техника за рубежом. Атомная техника за рубежом. 1990. № 8. С. 9-13.

8. Technical reports series. International Atomic Energy Agency. 1988. No. 286. P. 1-90.

9. Tobler L., Paja S. Enoiron. Radio Et. 1988. No. 3(6). P. 225-245.

10. Ламке Ф. Дезактивация металлических поверхностей, загрязненных тритием: пат. 8700017 ФРГ; опубл. 18.07.1988.

11. Золотарёва Р. Н. Теория и практика сорбционных процессов. Журнал Воронежского государственного универcumema. 1982. № 15. C. 84-88.

12. Childs E., Jong J. Nuclear Technology. Nuclear Engineering and Technology. 1987. No. 2(54). P. 208-215.

13. Кельцев Н. В. Основы адсорбционной техники. 2-ое изд. доп. и перераб. Москва : Химия, 1984. 270 с.

14. Богуславский В. Б., Грузев Н. И., Скляров В. П. Радиационная безопасность и защита АЭС. 1977. № 3. С. $27-42$.

Надійшла до редколегіï 14.09.2021 Схвалена до друку 16.11.2021

\author{
Відомості про авторів: \\ Писарєв Анатолій Васильович \\ кандидат військових наук доцент \\ доцент Національної академії \\ Національної гвардії України, \\ Харків, Україна \\ https://orcid.org/0000-0003-4527-0410 \\ Радченко Ігор Олександрович \\ кандидат військових наук доцент \\ завідувач кафедри Національної академії \\ Національної гвардії України, \\ Харків, Україна \\ https://orcid.org/0000-0003-2023-1568
}

\author{
Information about authors: \\ Anatolii Pisarev \\ $\mathrm{PhD}$ in Military Science Associate Professor \\ Associate Professor \\ of National Academy National Guard of Ukraine, \\ Kharkiv, Ukraine \\ https://orcid.org/0000-0003-4527-0410 \\ Igor Radchenko \\ $\mathrm{PhD}$ in Military Science Associate Professor \\ Head of the Department of National \\ Academy National Guard of Ukraine, \\ Kharkiv, Ukraine \\ https://orcid.org/0000-0003-2023-1568
}


Лазутський Анатолій Федорович кандидат військових наук доцент начальник штабу ЦЗ ДПТНЗ

"Харківське вище професійне училище сфери послуг”,

Харків, Україна

https://orcid.org// 0000-0002-9203-6638

Тузіков Сергій Анатолійович кандидат технічних наук доцент доцент кафедри

Харківського національного

університету Повітряних Сил ім. І. Кожедуба, Харків, Україна

https://orcid.org/0000-0001-5919-1137

\section{Писарєв Сергій Анатолійович}

старший викладач

Інституту танкових військ НТУ “ХПІ”,

Харків, Україна

https://orcid.org/0000-0002-7547-8629

Молодцов Віктор Арсентійович

кандидат військових наук доцент доцент Національної академії

Національної гвардії України,

Харків, Україна

https://orcid.org/0000-0002-7148-6170
Anatolii Lazutsky

$\mathrm{PhD}$ in Military Science Associate Professor

Chief of Staff of Civil Protection SVTEI

"Kharkiv Higher Vocational School

of the Service Industry",

Kharkiv, Ukraine

https://orcid.org/ 0000-0002-9203-6638

\section{Sergei Tuzikov}

$\mathrm{PhD}$ in Engineering Associate Professor

Associate Professor

of Ivan Kozhedub Kharkiv

National Air Force University,

Kharkiv, Ukraine

https://orcid.org/0000-0001-5919-1137

\section{Serhii Pisarev}

Senior Lecturer

of Institute of Tank Armies NTU "KhPI",

Kharkiv, Ukraine

https://orcid.org/0000-0002-7547-8629

\section{Viktor Molodsov}

$\mathrm{PhD}$ in Military Science Associate Professor

Associate Professor of National Academy

of National Guard of Ukraine,

Kharkiv, Ukraine

https://orcid.org/0000-0002-7148-6170

\title{
АНАЛИЗ СПОСОБОВ ДЕЗАКТИВАЦИИ ЭЛЕМЕНТОВ ВООРУЖЕНИЯ ОГРАНИЧЕННЫХ РАЗМЕРОВ С ИСПОЛЬЗОВАНИЕМ ЭЛЕКТРИЧЕСКОГО ПОЛЯ
}

\author{
А.В. Писарев, И.А. Радченко, А.Ф. Лазутский, С.А. Тузиков, С.А. Писарев, В.А. Молодцов
}

В данной статье авторами рассмотрены актуальный вопрос увеличения эффективности дезактивации образцов вооружения и военной техники при использовании жидкостных способов при условии применения совместного действия электрического поля и химических реагентов, образующих дезактивирующий раствор. Проведен детальньй анализ и теоретические расчеть результатов погружения образиов вооружения в дезактивируюший раствор, что значительно повымает эффективность обработки по сравнению с водной средой, электрохимическая дезактивация приводит к дальнейшему росту эффективности обработки. Описанная связь между затратами электролита, напряжением между электродами и удельной скоростью растворения верхнего загрязненного слоя оборудования. Проведенньй сравнительный анализ эффективной дезактивации в зависимости от плотности тока и продолжительности обработки, приведены преимущества использования электрохимической дезактивачии. Сделаны выводы о возможном сочетании действия электрического поля и ионообменной адсорбции, электрического поля и механических усилий, использование импульсного реверсного и особенно знакопеременного тока.

Ключевые слова: электрохимическая дезактивация, химическая дезактивация, эффективность дезактивации, коэффициент дезактивации, полнота дезактивации, полусухой способ электрической дезактивации.

\section{ANALYSIS OF METHODS FOR DEACTIVATING WEAPON ELEMENTS OF LIMITED SIZES USING AN ELECTRIC FIELD}

\author{
A. Pisarev, I. Radchenko, A. Lazutsky, S. Tuzikov, S. Pisarev, V. Molodsov
}

In this article, the authors consider the topical issue of increasing the efficiency of decontamination of weapons and military equipment when using liquid methods, provided that the combined action of an electric field and chemical reagents that form a deactivating solution is used. A detailed analysis and theoretical calculations of the results of immersion of we apons samples in deactivating solutions have been carried out, which significantly increases the processing efficiency in comparison with an aqueous medium, electrochemical deactivation leads to a further increase in the processing efficiency. Described the relationship between the consumption of electrolyte, the voltage between the electrodes and the specific rate of dissolution of the top contaminated layer of equipment. The comparative analysis of effective decontamination depending on the current density and the duration of treatment, the advantages of using electrochemical decontamination are given. Conclusions are made about a possible combination of the action of an electric field and ion-exchange adsorption, an electric field and mechanical forces, the use of a pulsed reverse and especially an alternating current. Using the example of vehicles, a comparison was made between the observer's ability to separate the depicted world with his ability to detect, distinguish and recognize real objects. As a result, each level of vision is assigned the number of resolving half-periods of an equivalent line measure within the minimum (critical) size of the object. In this case, the equation for transferring the image to a scattering medium was used, an equation was obtained to determine the visibility range of spatially extended objects for the case of observation with the naked eye for daytime illumination conditions. Based on the statistical processing of the experimental results, a relationship was established between the characteristics of video systems when observing standard test objects (world) and the quality of vision in real conditions.

Keywords: electrochemical decontamination, chemical decontamination, decontamination efficiency, decontamination factor, completeness of decontamination, semi-dry method of electrical decontamination. 